\title{
Cost effectiveness of DNA diagnosis for four monogenic diseases
}

\author{
A A P M van der Riet, B A van Hout, F F H Rutten
}

\begin{abstract}
In this paper the costs and benefits associated with DNA diagnosis of subjects who are at risk of having a child with a monogenic disease and who seek genetic counselling because of their reproductive plans are predicted under various assumptions using a mathematical model. Four monogenic diseases have been considered: cystic fibrosis, Duchenne muscular dystrophy, myotonic dystrophy, and fragile $X$ syndrome. Counselling (triggered by previous information) on the basis of DNA diagnosis is compared to the situation that only risk evaluation based on pedigree analysis is possible. The results show for each disease that with DNA diagnosis, couples can be more confident in choosing (further) offspring leading to the birth of more healthy children while the number of affected children is reduced. The costs minus savings within the health care sector depend on the prior risks and on the future burden of the monogenic illness under consideration. DNA diagnosis of relatively "low" prior risks of a child with CF (for example, 1:180, 1:240 and 1:480) leads to costs instead of savings. For higher prior risks of CF and for the three other diseases, DNA diagnosis produces considerable savings. This result remains valid when assumptions regarding behaviour, reproduction, and receiving DNA diagnosis under different circumstances are varied.

(F Med Genet 1997;34:741-745)
\end{abstract}

Keywords: genetic counselling; DNA diagnosis; cost effectiveness

DNA diagnosis has become an important part of genetic counselling as it is being applied to a growing number of monogenic diseases for carrier screening and prenatal diagnosis. Seven genetic centres perform DNA diagnosis in The Netherlands. The Health Insurance Executive Board initiated an economic appraisal study in 1992 to support a decision about reimbursement and about licensing of these facilities, which we report on here.

This study focuses on the costs and benefits associated with DNA diagnosis of subjects who are at risk of having a child with a monogenic disease and who seek genetic counselling because of their reproductive plans. "At risk" in this research means that couples who ask for information are related to an affected person. This complies with the indications for genetic counselling of monogenic hereditary diseases in The Netherlands. In genetic counselling there are two situations to which DNA diagnosis may apply: (1) when a person at risk wants to know if he or she is a carrier of a genetic disease (carrier screening or presymptomatic diagnosis), and (2) when a pregnant couple wants to know if the fetus is disadvantaged (prenatal diagnosis). Both applications are considered here.

The costs and benefits of DNA diagnosis are predicted under various assumptions of reproduction decisions using a mathematical model (fig 1) and are represented for four monogenic diseases: cystic fibrosis, Duchenne muscular dystrophy, myotonic dystrophy, and fragile $\mathrm{X}$ syndrome.

\section{Methods}

\section{ALTERNATIVES}

In an analysis of cost effectiveness, the costs and benefits of a defined health care programme are compared with costs and benefits of one or more alternatives. This study compares DNA diagnosis with the situation that only risk evaluation based on pedigree analysis is possible. As DNA diagnosis is technically superior to other diagnostic tests, the proposed comparison is the most relevant for showing the benefits of genetic counselling in general and DNA diagnosis in particular. In both situations retrospective counselling (triggered by previous information) is the policy under consideration here. This means that genetic counselling is only provided after the birth of the first affected child in a family (or after the identification of an index patient in a family). The availability of DNA diagnosis may prevent the parents from having a second affected child and provides the possibility of having at least one other healthy child by making use of prenatal diagnosis. Other relatives of an affected child may also be screened if such information is useful (for example, in relation to a reproductive decision).

\section{DECISIONS ON REPRODUCTION AND ASSOCIATED} CHANCES

A model (fig 1) is used incorporating assumptions about several decisions on reproduction and about associated chances of healthy progeny. The decisions on reproduction are derived from published research or expert opinion. Almost no disease specific information about these decisions was available, so for all diseases, except cystic fibrosis, baseline assumptions are used to measure the costs and benefits of the interventions compared. The 


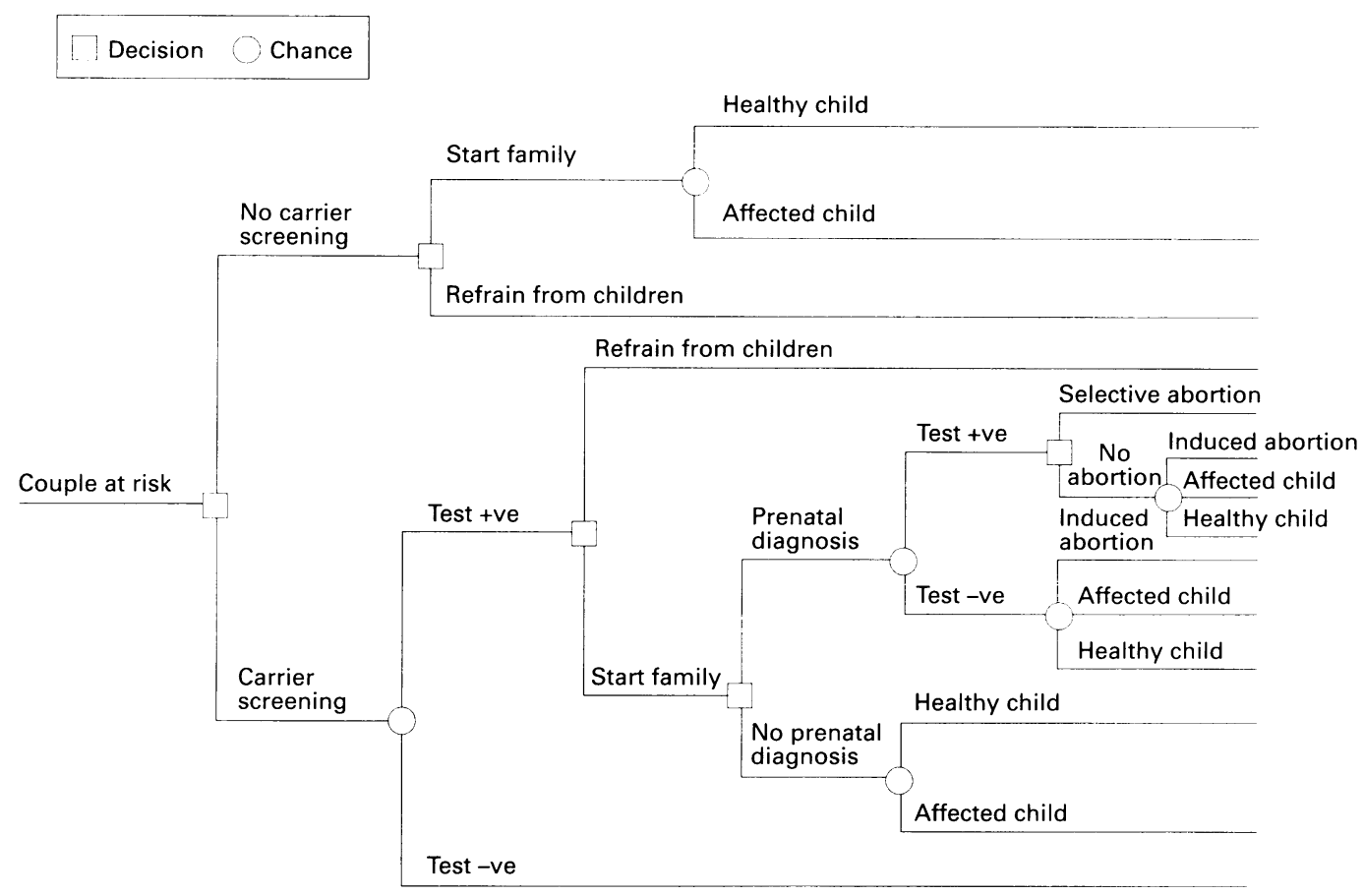

Figure 1 Model reproductive decisions and chances.

successive assumptions regarding reproductive decisions and references to published reports are shown in table 1. Furthermore a number of probabilities regarding incidence of illness are incorporated in the model: risk of infertility $10 \%,{ }^{1}$ risk of induced abortion after chorionic villus sampling $1 \%,{ }^{2}$ and conditional risks of an affected or a healthy child.

EFFECTS

The objective of genetic counselling, according to the definition of the WHO, is to help people with a genetic disadvantage to live and to reproduce as normally as possible. ${ }^{13}$ This means that DNA diagnosis for retrospective genetic counselling enables couples at risk to take informed decisions about (further) reproduction. In this way they may complete their families with minimal risk. A traditional cost effectiveness analysis, where costs per life year gained or per QALY (quality adjusted life year) gained are measured, is not appropriate here since the different dimensions in which benefits can be expressed cannot be aggregated to a single summary outcome measure. The effects relate to information about genetic risks available to a family, a better chance of healthy posterity, and, on the negative side, a higher risk of a terminated pregnancy. Thus, the effects in this analysis are presented as the differences between the situation with DNA diagnosis and the situation that only pedigree analysis is possible as regards the numbers of couples choosing (further) offspring and getting pregnant, healthy children, affected children, and terminated pregnancies.

CosTs

Only the costs within the health care system, shown in table 2, are considered here. The costs of diagnosis (carrier screening and prenatal diagnosis) are based on the average costs of a test in four major DNA laboratories in The Netherlands. The costs of deliveries and the costs of selective or induced abortion are based on Dutch tariffs and the costs of treatment of the monogenic diseases are based on global "burden of illness" studies or published

Table 1 Assumptions about reproductive decisions of couples at risk (ranges used in sensitivity analysis)

\begin{tabular}{|c|c|c|c|}
\hline Interventions & $\%$ at risk couples choosing & Risk of affected child $>10 \%$ * & Risk of affected child $<10 \% \dagger$ \\
\hline $\begin{array}{l}\text { No form of carrier or prenatal } \\
\text { diagnosis available }\end{array}$ & (Further) offspring & $\begin{array}{l}50 \% \ddagger \\
\text { CF } 30 \% \S(30-70 \%)\end{array}$ & $80 \%$ \\
\hline DNA diagnosis available & $\begin{array}{l}\text { Carrier screening } \\
\text { (Further) offspring } \\
\text { Prenatal diagnosis } \\
\text { Termination of pregnancy } \\
\text { when the fetus is affected }\end{array}$ & $\begin{array}{l}100 \% \| \\
85 \% \dagger+(60-100 \%) \\
90 \% \neq \ddagger(60-100 \%) \\
99 \% § S\end{array}$ & $90 \% \star \star(60-100 \%)$ \\
\hline
\end{tabular}

$\star$ Risk of an affected child $>10 \%$ when a couple already has an affected child or when carrier screening gives an unfavourable test result.

†Prior risk of an affected child $<10 \%$ when a couple is related to an affected child

$\ddagger$ Emery et al, ${ }^{3}$ Sorenson et al, ${ }^{4}$ Frets. ${ }^{5}$

SAverage of Dankert-Roelse," Kaback et al, ${ }^{7}$ Leonard et al.

TAverage of Sorenson et al, ${ }^{,}$Frets.

IAverage of Sorenson $e t$ al, '

$\star \star$ Personal communication from genetic clinicians of four clinical centres in Groningen, Leiden, Rotterdam, and Nijmegen. t+Frets. ${ }^{5}$

㧊Tybkjaer," personal communication from genetic clinicians of four clinical centres in Groningen, Leiden, Rotterdam, and Nijmegen.

ofKloosterman, ${ }^{10}$ Brandenburg, ${ }^{11}$ Beekhuis et al. ${ }^{12}$ 
Table 2 Cost estimates used in the model in Dfl (1994 exchange rate US\$ Dfl 1.82)

\begin{tabular}{lrr}
\hline & $\begin{array}{c}\text { Baseline } \\
\text { estimate }\end{array}$ & Range sensitivity analysis \\
\hline DNA test & 1200 & $500-2500$ \\
Delivery & 3916 & \\
Abortion (13 weeks) & 987 & \\
Curettage & 668 & \\
Life time cost of cystic fibrosis & 1319284 & $250000-2500000$ \\
Discounted by 5\% & 545968 & \\
Life time cost of Duchenne muscular dystrophyt & 747173 & $250000-2500000$ \\
Discounted by 5\% & 487723 & \\
Life time cost of congenital myotonic dystrophyt & 1187919 & $250000-2500000$ \\
Discounted by 5\% & 424635 & \\
Life time cost of fragile X syndromet & 4107920 & $250000-2500000$ \\
Discounted by 5\% & 820017 & \\
\end{tabular}

^Study Group Costs and Effects of CF Carrier Screening, 1994. iMGZ, Erasmus University Rotterdam.

†Global burden of illness studies by Study Group Costs and Effects of DNA Diagnosis, 1994. iMTA, Erasmus University Rotterdam.

research.$^{14}$ Expert panels provided information on the profile of resource use in the treatment of the other three diseases, and cost studies were performed to estimate the relevant unit costs of these resource use items. The total burden of illness was calculated by multiplying the volume of used resources with the unit costs.

Table 2 shows the estimated life time cost and the discounted costs for each disease. To allow comparison of the burden of illness across diseases and to set this against the investment in DNA diagnosis, the flow of costs over time has to be expressed in a total amount representing the present value of that flow. This is done by discounting costs in later periods using a discount rate of $5 \%$.

\section{Results}

EFFECTS

Table 3 shows the effects of DNA diagnosis for the selected illnesses in distinct risk groups. These effects are the result of calculations based on the mathematical model shown in fig 1. The effects are calculated for each disease in a group of 100 couples who consult a genetic counsellor. As an example we will explain how these effects are calculated in the case of CF. It is assumed that couples already have an affected child. In the situation that no form of carrier or prenatal diagnosis is available, $30 \%$ of parents at risk choose further offspring, the risk of a CF child being $25 \%$. This results in 30 pregnancies, 7.5 affected children, and 22.5 healthy children per 100 consulting couples. In the situation that DNA diagnosis is available, $85 \%$ of the carriers choose further offspring,
$90 \%$ choose to have prenatal diagnosis, and $99 \%$ of the couples choose to terminate the pregnancy when the child is affected. This results in 85 pregnancies, 2.3 affected children, 63.2 healthy children, and 19.5 terminated pregnancies (including 1\% induced abortions after chorionic villus sampling) per 100 consulting couples. The comparison of the two above mentioned situations results in +55 pregnancies, +40.7 healthy children, -5.2 affected children, and +19.5 terminated pregnancies as the effect of DNA diagnosis for 100 consulting couples.

The effects per disease with a specific distribution of prior risks are shown in table 4 . The results for each individual disease are discussed below.

\section{Cystic fibrosis}

Cystic fibrosis (CF) is a severely debilitating chronic disease and causes a short life expectancy. In families where a CF mutation is already known, the mutation can be definitely identified or excluded. Analysis of the 10 most frequent mutations identifies $85 \%$ of all CF mutations. ${ }^{15}$ The results show that with DNA diagnosis couples in all risk categories (a parent, man or woman, is sib, uncle/aunt, nephew/niece) can be more confident in choosing (further) offspring leading to the birth of more healthy children while the number of affected children can be reduced.

\section{Duchenne muscular dystrophy}

Duchenne muscular dystrophy (DMD) is a lethal, recessive, $\mathrm{X}$ linked neuromuscular disease. DNA diagnosis can identify or exclude a DMD mutation in $96.5 \%$ of female carriers or male fetuses in families where the mutation is already known (B Bakker, personal communication, 1994). The other $3.5 \%$ of the female carriers or male fetuses in these families have a risk of $1: 2$ for a DMD mutation. The results of DNA diagnosis are again calculated for four risk groups of 100 couples related to a DMD patient (woman is mother and sister, mother, sib, niece). Here also similar positive results can be reported as in the case of cystic fibrosis.

\section{Myotonic dystrophy}

Myotonic dystrophy (DM) is an autosomal dominant disorder and is generally considered as a disease of adult life or adolescence. The patients' illness is more severe when the clinical

Table 3 Effects of "DNA diagnosis" versus "pedigree analysis" in distinct risk groups

\begin{tabular}{|c|c|c|c|c|}
\hline \multirow{2}{*}{$\begin{array}{l}\text { Disease }+ \text { prior risks } \\
\text { Prior risk of parents being carriers } \\
\text { (affected child) }\end{array}$} & \multicolumn{4}{|c|}{ Effects of DNA diagnosis for 100 consulting couples } \\
\hline & $\begin{array}{l}\text { Couples getting } \\
\text { pregnant }\end{array}$ & Healthy children & Affected children & $\begin{array}{c}\text { Terminated } \\
\text { pregnancies }\end{array}$ \\
\hline $\begin{array}{l}\text { CF } 1(1: 4) \\
\text { CF } 1: 45(1: 180) \\
\text { CF } 1: 60(1: 240) \\
\text { CF 1:120(1:480) } \\
\text { DMD 1 } 1: 2) \\
\text { DMD } 2: 3(1: 3) \\
\text { DMD 1:3(1:6) } \\
\text { DMD 1:6(1:12) } \\
\text { CMD 1 } 1: 2) \\
\text { CMD 1 } 1: 3) \\
\text { FraX 1 } 1(45 \%) \\
\text { FraX 1:2(22.5\% }\end{array}$ & $\begin{array}{l}+55.0 \\
+17.8 \\
+17.8 \\
+17.9 \\
+35.0 \\
+40.0 \\
+41.0 \\
+16.0 \\
+35.0 \\
+32.9 \\
+35.0 \\
+38.9\end{array}$ & $\begin{array}{l}+40.7 \\
+17.7 \\
+17.8 \\
+17.9 \\
+25.6 \\
+38.3 \\
+41.7 \\
+18.0 \\
+17.1 \\
+10.1 \\
+25.9 \\
+38.4\end{array}$ & $\begin{array}{l}-5.2 \\
-0.2 \\
-0.2 \\
-0.1 \\
-10.2 \\
-7.3 \\
-2.8 \\
-2.6 \\
-20.4 \\
-8.3 \\
-7.9 \\
-3.0\end{array}$ & $\begin{array}{l}+19.5 \\
+0.3 \\
+0.2 \\
+0.1 \\
+19.6 \\
+9.0 \\
+2.0 \\
+0.6 \\
+38.3 \\
+31 \\
+17 \\
+3.4\end{array}$ \\
\hline
\end{tabular}


Table 4 Effects of DNA diagnosis versus pedigree analysis in distributed risk groups

\begin{tabular}{|c|c|c|}
\hline \multirow{2}{*}{$\frac{\text { Disease }}{\text { Cystic fibrosis` }}$} & \multicolumn{2}{|c|}{ Effects of DNA diagnosis for 100 consulting couple } \\
\hline & +38 & Couples choosing (further) offspring \\
\hline & +30 & Healthy children \\
\hline & -3 & Affected children \\
\hline & +11 & Terminated pregnancies \\
\hline \multirow[t]{4}{*}{ Duchenne muscular dystrophy } & +33 & Couples choosing (further) offspring \\
\hline & +31 & Healthy children \\
\hline & -6 & Affected children \\
\hline & +8 & Terminated pregnancies \\
\hline \multirow[t]{4}{*}{ Myotonic dystrophy $\ddagger$} & +34 & Couples choosing (further) offspring \\
\hline & +14 & Healthy children \\
\hline & -15 & Affected children \\
\hline & +35 & Terminated pregnancies \\
\hline \multirow[t]{4}{*}{ Fragile $\mathrm{X}$ syndrome $₫$} & +37 & Couples choosing (further) offspring \\
\hline & +32 & Healthy children \\
\hline & -5 & Affected children \\
\hline & +10 & Terminated pregnancies \\
\hline
\end{tabular}

Percentages of couples with different prior risks of an affected child

* $(55 \% 1: 4)(15 \% 1: 180)(15 \% 1: 240)(15 \% 1: 480)$

$+(25 \% 1: 2)(25 \% 1: 3)(25 \% 1: 6)(25 \% 1: 12)$

$\ddagger(50 \% \quad 1: 2)(50 \% \quad 1: 3)$

$\$(50 \% 0.45)(50 \% 0.225)$

Table 5 Additional (+) costs or savings (-) of DNA diagnosis versus pedigree analysis per consulting couple in $D f$

\begin{tabular}{lll}
\hline Disease & $\begin{array}{l}\text { Prior risk of parents being carriers } \\
\text { (prior risk of affected child) }\end{array}$ & $\begin{array}{l}\text { Costs minus savings for one } \\
\text { consulting couple }\end{array}$ \\
\hline Cystic fibrosis & $1(1: 4)$ & -62621 \\
Cystic fibrosis & $1: 45(1: 180)$ & +42 \\
Cystic fibrosis & $1: 60(1: 240)$ & +854 \\
Cystic fibrosis & $1: 120(1: 480)$ & +2075 \\
Duchenne muscular dystrophy & $1(1: 2)$ & -71751 \\
Duchenne muscular dystrophy & $2: 3(1: 3)$ & -50200 \\
Duchenne muscular dystrophy & $1: 3(1: 6)$ & -16956 \\
Duchenne muscular dystrophy & $1: 6(1: 12)$ & -16254 \\
Myotonic dystrophy & $1(1: 2)$ & -226347 \\
Myotonic dystrophy & $1(1: 3)$ & -90223 \\
Fragile X syndrome & $1( \pm 45 \%)$ & -321417 \\
Fragile X syndrome & $1: 2( \pm 22.5 \%)$ & -118034 \\
\hline
\end{tabular}

symptoms are present at an earlier age. ${ }^{16}$ The congenital variant is the most severe form of $\mathrm{DM}$ and is only seen in the offspring of mothers who have the adult variant of $\mathrm{DM} .{ }^{17} \mathrm{~A}$ combination of mutation analysis, marker analysis, and clinical symptoms identifies or excludes DM definitely. ${ }^{18}$ This study only takes into account the congenital form of DM $(\mathrm{CDM})$ and is based on calculations of two groups of 100 consultands at risk of a CDM child (woman is DM patient and mother of CDM child, woman is DM patient). Therefore, the true effects and savings also taking into account the positive effects as a consequence of minor DM disorders will be higher than reported here. Here the number of affected children avoided is higher but at the cost of more terminated pregnancies, because the two risk groups that are analysed have larger prior risks of an affected (CDM) child than the analysed risk groups of CF and DMD.

\section{Fragile $X$ syndrome}

Fragile $X$ syndrome $(\mathrm{fra}(\mathrm{X}))$ is the most frequent hereditary form of mental retardation. The mutation in men always results in severe mental retardation, compared with a range from completely normal to severely retarded in women. DNA diagnosis can definitely identify or exclude the fra(X) mutation. ${ }^{19}{ }^{20}$ Cost and effect measurement in this analysis is limited to the risk of a son with the fra $(\mathrm{X})$ (lower bound estimate of positive effects) and is done for two groups of 100 couples with prior risks of $45 \%$ and $22.5 \%$ for a son with the fra $(\mathrm{X})$ (woman has son with $\mathrm{fra}(\mathrm{X})$, woman is sister of fra $(\mathrm{X})$ patient). Positive effects of the use of DNA diagnosis can also be reported here.

\section{costs}

Table 5 shows the costs minus savings of the four diseases. The costs minus savings relate strongly to the prior risks and to the burden of illness. DNA diagnosis of relatively "low" prior risks of a child with CF (for example, 1:180, $1: 240$, and $1: 480$ or the prior risk of a CF child if one of the parents is a sib, an aunt/uncle, or nephew/niece, respectively of a CF child) leads to costs instead of savings. For all other risks groups, DNA diagnosis produces considerable savings.

\section{SENSITIVITY ANALYSIS}

A univariate sensitivity analysis was done by varying subsequently all base line assumptions. The results per disease with a specific distribution of prior risks (as in table 4 ) are presented in table 6.

Under various assumptions regarding the choice of reproduction when no DNA diagnosis is available and the choice of prenatal

Table 6 Results of sensitivity analysis: effects of DNA diagnosis versus pedigree analysis for 100 consulting couples in distributed risk groups

\begin{tabular}{|c|c|c|c|c|c|c|}
\hline \multirow[b]{2}{*}{ Disease } & \multicolumn{3}{|c|}{$\begin{array}{l}\% \text { couples getting pregnant with only pedigree analysis (variation } 30-70 \% \text { ) Risk } \\
\text { of affected child }>10 \%\end{array}$} & \multicolumn{3}{|c|}{$\%$ couples choosing (DNA) prenatal diagnosis (variation $60-100 \%$ ) } \\
\hline & $30 \%$ & $70 \%$ & & $60 \%$ & $100 \%$ & \\
\hline \multirow[t]{5}{*}{ Cystic fibrosis } & +38 & +16 & Couples getting pregnant & +38 & +38 & Couples getting pregnant \\
\hline & +30 & +14 & Healthy children & +30 & +30 & Healthy children \\
\hline & -3 & -8 & Affected children & +1 & -4 & Affected children \\
\hline & +11 & +11 & Terminated pregnancies & +7 & +12 & Terminated pregnancies \\
\hline & -34000 & -107000 & Cost savings per couple in Dfl & +12000 & -49000 & Cost savings per couple in Dfl \\
\hline \multirow{5}{*}{$\begin{array}{l}\text { Duchenne } \\
\text { muscular } \\
\text { dystrophy }\end{array}$} & +48 & +19 & Couples getting pregnant & +33 & +33 & Couples getting pregnant \\
\hline & +43 & +19 & Healthy children & +31 & +31 & Healthy children \\
\hline & -3 & -8 & Affected children & -3 & -7 & Affected children \\
\hline & +8 & +8 & Terminated pregnancies & +5 & +9 & Terminated pregnancies \\
\hline & -20000 & -58000 & Cost savings per couple in Dfl & -21000 & -45000 & Cost savings per couple in Dfl \\
\hline \multirow{5}{*}{$\begin{array}{l}\text { Myotonic } \\
\text { dystrophy }\end{array}$} & +53 & +15 & Couples getting pregnant & +34 & +34 & Couples getting pregnant \\
\hline & +25 & +3 & Healthy children & +14 & +14 & Healthy children \\
\hline & -6 & -22 & Affected children & -3 & -18 & Affected children \\
\hline & +35 & +35 & Terminated pregnancies & +23 & +39 & Terminated pregnancies \\
\hline & -68000 & -250000 & Cost savings per couple in Dfl & -30000 & -201000 & Cost savings per couple in Dfl \\
\hline \multirow{5}{*}{$\begin{array}{l}\text { Fragile } \mathrm{X} \\
\text { syndrome }\end{array}$} & +56 & +18 & Couples getting pregnant & +37 & +37 & Couples getting pregnant \\
\hline & +48 & +16 & Healthy children & +32 & +32 & Healthy children \\
\hline & -3 & -9 & Affected children & -2 & -7 & Affected children \\
\hline & +10 & +10 & Terminated pregnancies & +7 & +11 & Terminated pregnancies \\
\hline & -107729 & -347467 & Cost savings per couple in Dfl & -79680 & -266443 & Cost savings per couple in Dfl \\
\hline
\end{tabular}


diagnosis, the effects of DNA diagnosis in CF couples remain positive. Only when $60 \%$ of the couples, with a 1 in 4 risk of a child with $C F$, use prenatal diagnosis will there be a slight increase in the number of births of affected children in a group of 100 consultands and consequently additional costs of Dfl 12000 per consulting couple instead of savings. When $70 \%$, or more, of these couples at risk make use of prenatal diagnosis the number of affected children will decrease. In the sensitivity analysis for $\mathrm{DMD}, \mathrm{DM}$, and $\mathrm{fra}(\mathrm{X})$ the positive effects and savings of the baseline estimates do not change into any negative consequences.

Also, when other assumptions are varied (use of DNA diagnosis $60-100 \%$, further offspring with DNA diagnosis $60-100 \%$, sensitivity of carrier diagnosis 0.9-1.0, costs of diagnosis Dfl $500-2500$, costs of illness Dfl $250000-$ 2500000 ), the effects of DNA diagnosis remain positive.

\section{Discussion}

The effects of DNA diagnosis are in general positive for each disease and for all risk groups considered and include an increase in the number of couples choosing (further) offspring, an increase in births of healthy children, and a decrease in the number of affected children. On the negative side an increase is expected in the number of affected pregnancies that may be terminated. The availability of DNA diagnosis also results in an increase in the number of births of healthy carriers. Furthermore, DNA diagnosis induces considerable savings in the health care budget with the exception of the situation where both parents have a prior risk of 1:45 or lower of being carriers of the CF mutation. The savings increase with the burden of care for a particular disease and with higher prior risks.

Although the results differ across disease categories they suggest that positive effects and savings may also be produced in other disease categories where the health care expenditure for treatment is considerable and where prior risks of affected children are above the level of about $1 \%$. As DNA diagnosis appears to be quite cost effective in the diseases considered here, one may like to investigate a broader application of this counselling service, for example, by not only helping couples presenting themselves with a request for counselling but through actively searching for families with high risk profiles (for example, by testing the mentally disabled for $\mathrm{fra}(\mathrm{X})$ ). In cost effectiveness research in CF screening there are indications that a programme for CF screening leads to savings. ${ }^{21}$
On the basis of the results reported here, the Health Insurance Executive was informed that the current Dutch practice of genetic counselling is quite a cost effective health care intervention. The board subsequently decided to incorporate this activity into the package of health care services available to all those publicly insured in The Netherlands.

We thank the Health Insurance Executive Board CommitteeDNA analysis who helped us during the study and the experts for their valuable information about DNA diagnosis and genetic counselling. We are especially grateful to Prof dr C H C M Buys for his helpful remarks on a draft version of this paper.

1 Hille E, de Kroon M. Epidemiologie van infertiliteit. Institute for MTA, Erasmus University Rotterdam, 1992.

2 Gezondheidsraad. Advies inzake planningsregeling klinische genetica. s' Gravenhage: Gezondheidsraad, 1992.

3 Emery AEH, Raeburn JA, Skinner R, Holloway S, Lewis P. Prospective study of genetic counselling. BMF 1979; 1253-6.

4 Sorenson JR, Scotch JP, Swazey JP, Wertz DC, Heeren TC. Reproductive plans of genetic counseling clients not eligible for prenatal diagnosis. Am $\mathcal{F}$ Med Genet 1987;28 345-52.

5 Frets PG. The reproductive decision after genetic counseling. Dissertation, Erasmus University Rotterdam, 1990.

6 Dankert-Roelse JE. Effects of neonatal screening for cystic fibrosis. Dissertation, University of Groningen, 1988.

7 Kaback M, Zippin D, Boyd P, Cantor R. Attitudes toward prenatal diagnosis of cystic fibrosis among parents of affected children. In: Lawson D, ed. Cystic fibrosis horizons. Chichester: John Wiley, 1994.

8 Leonard CO, Chase GA, Childs B. Genetic counseling: a consumers view. N Engl f Med 1972;287:433-9.

9 Tybkjaer HW. Behavioural changes in CF families' reproductive pattern after introduction of prenatal diagnosis. Danish CF Association, 1992

10 Kloosterman MD. Prenatale diagnostiek, enige cijfers over de laatste jaren. Ned Tijdschr Obstet Gynaecol 1990;103:23842 .

11 Brandenburg H. Prenatal diagnosis in women of advanced maternal age. Dissertation, Erasmus University Rotterdam, 1992

12 Beekhuis JR, Mantingh A, De Wolf BTHM, Van Lith JMM Breed ASPM. Serumscreening van zwangeren op foetale neurale-buisdefecten en Down syndroom; eerste ervaringen in Nederland. Ned Tijdschr Geneeskd 1993;137:1303-7.

13 World Health Organization Advisory Group on Hereditary Diseases. Community approaches to the control of hereditary diseases. Unpublished WHO document HMG/WG/85.4 1985.

14 Wildhagen MF, Verhey JBGM, et al. Cost of care of patients with cystic fibrosis in the Netherlands in 1990-1991. Thorax 1996;51:298-301.

15 Halley DJJ, van den Ouweland AMW, Van der Hout AH, Scheffer H. Overzicht van 5 jaar DNA-diagnostiek voo cysitische fyfrose. LOD Nieuwsbrief 1995;2:8-10.

16 Höweler CJ. A clinical and genetic study in myotonic dystrophy. Dissertation, Erasmus University Rotterdam, 1986.

17 Harper PS. Myotonic dystrophy. 2nd ed. London: Saunders, 1989.

18 Brunner HG, Nillesen W, Van Oost BA, et al. Presymptomatic diagnosis of myotonic dystrophy. $¥$ Med Genet 1992 matic diag

19 Oostra BA, Jacky PB, Brown WT, Rousseau F. Guidelines for the diagnosis of fragile X syndrome. $\mathcal{F}$ Med Genet 1993, 30:410-13.

20 Turner AM, Robinson H, Wake S, et al. Counseling risk figures for fragile $\mathrm{X}$ carrier females of varying band sizes for use in predicting the likelihood of retardation in their offspring. Am $\mathcal{F}$ Med Genet 1994;51:458-62.

21 Van de Laar J, Ten Kate LP. Preconceptionele screening op dragerschap voor cystische fibrose. Toetsing aan de Gezondheidsraad-criteria voor genetische screening. Ned Tijdschr Geneekd 1996;9:487-91. 